\title{
KEWENANGAN PROVOS DALAM MENGHADAPI PENYALAHGUNAAN SENJATA API OLEH ANGGOTA KEPOLISIAN
}

\author{
Dody Eko Wijayanto, SH, M.Hum
}

\begin{abstract}
Abstrak
Perkembangan kemajuan masyarakat yang cukup pesat, seiring dengan merebaknya fenomena supremasi hukum, hak asasi manusia, globalisasi, demokratisasi, desentralisasi, transparansi, dan akuntabilitas, telah melahirkan berbagai paradigma baru dalam melihat tujuan, tugas, fungsi, wewenang dan tanggung jawab Kepolisian Negara Republik Indonesia yang selanjutnya menyebabkan pula tumbuhnya berbagai tuntutan dan harapan masyarakat terhadap pelaksanaan tugas Kepolisian Negara Republik Indonesia yang makin meningkat dan lebih berorientasi kepada masyarakat yang dilayaninya. Oleh sebab itu keberhasilan pelaksanaan tugas Kepolisian Negara Republik Indonesia dalam memelihara keamanan dan ketertiban masyarakat, menegakkan hukum, dan melindungi, mengayomi serta melayani masyarakat, selain ditentukan oleh kualitas pengetahuan dan keterampilan teknis kepolisian yang tinggi sangat ditentukan oleh perilaku terpuji setiap anggota Kepolisian Negara Republik Indonesia di tengah masyarakat. Guna mewujudkan sifat kepribadian tersebut, setiap anggota Kepolisian Negara Republik Indonesia dalam melaksanakan tugas dan wewenangnya senantiasa terpanggil untuk menghayati dan menjiwai etika profesi kepolisian yang tercermin pada sikap dan perilakunya, sehingga terhindar dari petbuatan tercela dan penyalahgunaan wewenang.
\end{abstract}

\section{Kata Kunci : Kewenangan provos, Penyalahgunaan senjata api}

A. Pendahulua

\section{Latar Belakang Masalah} Undang-Undang Dasar

Negara Republik Indonesia Tahun 1945 menentukan secara tegas bahwa negara Indonesia adalah negara Hukum. Oleh sebab itu Kepolisian sebagai salah satu aparat penegak hukum berperan mewujudkan prinsip-prinsip negara hukum dalam kehidupan bermasyarakat dan bernegara.

Perkembangan kemajuan masyarakat yang cukup pesat, seiring dengan merebaknya fenomena supremasi hukum, hak asasi manusia, globalisasi, demokratisasi, desentralisasi, transparansi, dan akuntabilitas, telah melahirkan berbagai paradigma baru dalam melihat tujuan, tugas, fungsi, wewenang dan tanggung jawab Kepolisian Negara Republik Indonesia yang selanjutnya menyebabkan pula tumbuhnya berbagai tuntutan dan harapan masyarakat terhadap pelaksanaan tugas Kepolisian Negara Republik Indonesia yang makin meningkat 
dan lebih berorientasi kepada masyarakat yang dilayaninya. ${ }^{38}$

Oleh sebab itu keberhasilan pelaksanaan tugas Kepolisian Negara Republik Indonesia dalam memelihara keamanan dan ketertiban masyarakat, menegakkan hukum, dan melindungi, mengayomi serta melayani masyarakat, selain ditentukan oleh kualitas pengetahuan dan keterampilan teknis kepolisian yang tinggi sangat ditentukan oleh perilaku terpuji setiap anggota Kepolisian Negara Republik Indonesia di tengah masyarakat. Guna mewujudkan sifat kepribadian tersebut, setiap anggota Kepolisian Negara Republik Indonesia dalam melaksanakan tugas dan wewenangnya senantiasa terpanggil untuk menghayati dan menjiwai etika profesi kepolisian yang tercermin pada sikap dan perilakunya, sehingga terhindar dari petbuatan tercela dan penyalahgunaan wewenang. ${ }^{39}$

Setiap anggota kepolisian selaku aparatur penegak hukum dituntut tekad dan semangat yang sesuai dengan cita-cita, tujuan, visi dan misi profesi kepolisian, oleh karena itu segala tindakannya harus searah dan sejalan dengan tujuan, visi dan misi lembaga. Aparatur kepolisian juga harus memiliki kesadaran akan kewajiban

38 Penjelasan Umum Undang-Undang Nomor 2 Tahun 2002 tentang Kepolisian Negara Republik Indonesia.

39 Keputusan Kapolri Nomor 32 Tahun 2003 tentang Kode Etik Kepolisian Negara Republik Indonesia. profesionalnya. Profesionalisme merupakan kualitas dan tindak tanduk yang merupakan ciri mutu dari orang yang profesional. Profesionalisme Polri adalah sikap, cara berfikir, tindakan, dan perilaku, pelaksanaan pemolisiannya dilandasi ilmu kepolisian, yang diabdikan pada kemanusiaan atau melindungi harkat dan martabat manusia sebagai aset utama bangsa dalam wujud terpeliharanya keamanan, ketertiban, dan tegaknya hukum. Polisi yang professional akan mampu melakukan tindakan untuk $:^{40}$

1. Mengamati fenomena di sekelilinginya dengan cermat (observasi terhadap berbagai gejala atau peristiwa), menemukan data yang bermanfaat bagi pemolisiannya;

2. Menganalisa setiap gejala/ peristiwa/ fenomena yang terjadi secara kritis, dialektis, komparatif, maupun dealogis;

3. Melihat, meramalkan atau memprediksikan hubungan antara gejala yang satu dengan yang lainnya secara logis dan sistematis yang berguna dalam menentukan strategi-strategi pemolisiannya sebagai upaya preventif (crime prevention);

40 Sadjijono, Etika Profesi Hukum: Suatu Telaah Filosofis terhadap Konsep dan Implementasi dalam Pelaksanaan Tugas Profesi Polisi, Laksbang Mediatama, Surabaya, 2008, hlm 43-44. 
4. Memecahkan berbagai masalah sosial yang terjadi dalam masyarakat dan memberikan solusinya (problem solving policing), dan

5. Mengembangkan kreativitas dalam pemolisiannya sehingga dapat diterima oleh masyarakatnya dan berguna dalam kehidupan masyarakat, khususnya yang berkaitan dengan keamanan dan ketertiban yang dapat mendorong tumbuh dan berkembangnya kualitas hidup masyarakat.

\begin{tabular}{|c|c|}
\hline Untuk & terhindar \\
\hline perbuatan & tercela \\
\hline
\end{tabular}
Kepolisian dalam melaksanakan peran dan fungsinya, memiliki disiplin anggota dan susunan organisasi serta tata kerja yang disesuaikan dengan kepentingan pelaksanaan tugas dan wewenangnya guna mewujudkan keberhasilan pelaksanaan tugas Kepolisian itu sendiri. Hal tersebut diatur dalam Peraturan Pemerintah Nomor 2 Tahun 2003 tentang Peraturan Disiplin Anggota Kepolisian, serta Keputusan Presiden Nomor 70 Tahun 2002 tentang Organisasi dan Tata Kerja Kepolisian.

Peraturan disiplin anggota tersebut berisi kewajiban, larangan, sanksi, dan penyelesaian pelanggaran disiplin yang dilakukan oleh aparat polisi itu sendiri. Dalam peraturan disiplin anggota kepolisian tersebut terdapat pejabat yang berwenag menjatuhkan tindakan disiplin. Pejabat tersebut adalah atasan langsung, atasan tidak langsung, dan anggota provos kepolisian itu sendiri.

Seiring berkembangnya zaman, permasalahan dalam kehidupan masyarakat semakin kompleks, khususnya mengenai tindakan melawan hukum, terutama yang dilakukan oleh aparat Kepolisian itu sendiri. Salah satu tindakan melawan hukum yang timbul dari pemakaian senjata api tersebut berupa kelalaian anggota kepolisian yang mengakibatkan salah tembak. Berdasarkan tugas, fungsi, dan wewenang kepolisian, maka pejabat yang berhak melakukan tindakan disiplih adalah atasan langsung, atasan tidak langsung, dan provos.

Sebelum dijatuhkannya hukuman disiplin, provos atas perintah dari Ankum harus melakukan pemeriksaan terlebih dahulu terhadap anggota kepolisian yang disangka melakukan pelanggaran disiplin tersebut. Selain itu, Provos memiliki kewenangan untuk $:^{41}$

1. Melakukan pemanggilan dan pemeriksaan,

2. Membantu pimpinan menyelenggarakan

pembinaan dan penegakan disiplin, serta memelihara tata tertib kehidupan anggota kepolisian,

41 Pasal 22 Peraturan Pemerintah No.2 Tahun 2003 Tentang Peraturan Disiplin Anggota Kepolisian. 
3. Menyelenggarakan sidang disiplin atas perintah Ankum,

4. Melaksanakan putusan Ankum.

Apabila anggota kepolisian tersebut terbukti bersalah, maka akan dijatuhi hukuman disiplin yang hal tersebut merapakan kewenangan dari Ankum. Setelah sidang disiplin usai diselenggarakan, maka provos melakukan tugasnya yaitu pelaksanaan putusan sidang disiplin yang berupa penempatan dalam tempat khusus.

\section{Perumusan Masalah}

Berdasarkan latar belakang masalah tersebut di atas penulis mengetengahkan dua permasalahan yaitu:

a. Sejauh mana kewenangan Provos dalam menghadapi penyalahgunaan senjata api oleh anggota Kepolisian?

b. Bagaimana Prosedur Penanganan Dan Sanksi Disiplin Terhadap Penyalahgunaan Senjata Api Dinas?

\section{Tujuan Penelitian}

Dalam penelitian ini penulis mempunyai tujuan antara lain:

a. Untuk mengetahui sejauh mana kewenangan Provos dalam menghadapi penyalahgunaan senjata api oleh anggota Kepolisian.

b. Untuk mengetahui prosedur Penanganan Dan Sanksi Disiplin Terhadap Penyalahgunaan Senjata Api Dinas.

\section{B. Kajian Pustaka}

1. Pengertian Kepolisian dan Anggota Kepolisian

.Selama ini polisi dipahami sebagai suatu organ, lembaga atau istitusi, dan dengan istilah kepolisian dimaknai sebagai organ beserta fungsinya. Kadang-kadang luput dari perhatian, bahwa sebenarnya eksistensi lembaga itu sangat dipengaruhi oleh individu, orang perorangan (person) yang berada dalam lembaga dan memiliki peran penting dalam menggerakkan atau menjalankan lembaga, dengan kata lain yang berperan mengoperasionalkan fungsi dari lembaga tersebut, sehingga tercapai dan tidaknya tujuan, cita-cita, visi dan misi lembaga bergantung pada personel yang membadani lembaga tersebut, artinya efektifitas lembaga ditentukan oleh sumber daya manusianya. Masih ada sebagian orang yang mengartikan dan menilai terhadap kepolisian dilihat dari segi tampilannya saja. ${ }^{42}$

Polisi di manapun di dunia ini umumnya mempunyai dua peran sekaligus, yaitu ${ }^{43}$

a. Polisi adalah institusi yang bertugas menjaga dan memelihara keamanan dan ketertiban atau orde

42 Sadjijono, Etika Profesi Hukum: Suatu Telaah Filosofis terhadap Konsep dan Implementasi dalam Pelaksanaan Tugas Profesi Polisi, Laksbang Mediatama, Surabaya, 2008, hlm. 20.

43 Pudi Rahardi, Hukum Kepolisian (Profesionalisme dan Reformasi Polri), 2007, Laksbang Mediatama, Surabaya, hIm. 173. 


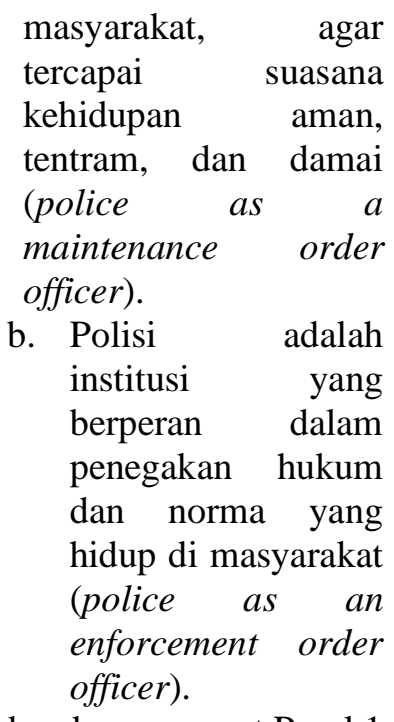

Sedangkan menurut Pasal 1

nomor 1 Undang-undang Nomor 2 Tahun 2002 tentang Kepolisian Negara Republik Indonesia Lembaran Negara Republik Indonesia Tahun 2002 Nomor 2, pengertian Kepolisian adalah segala hal-ihwal yang berkaitan dengan fungsi dan lembaga polisi sesuai dengan peraturan perundang-undangan.

$\begin{array}{lr}\text { Kepolisian } & \text { adalah } \\ \text { merupakan profesi yang dengan } & \\ \text { sadar mereka pilih melalui }\end{array}$ keputusan nuraninya. Di dalam kehidupan anggota kepolisian, ada dua norma yang menjadi dasar dalam berperilaku, yakni norma moral diri mereka sebagai manusia, dan norma yang diformulasikan oleh lembaga sebagai aturan bagaimana seharusnya berperilaku, antara lain etika profesi kepolisian. $^{44}$ Menurut Pasal 1 nomor 2 Undang-undang Nomor 2 Tahun 2002 tentang Kepolisian Negara Republik Indonesia Lembaran Negara Republik

\footnotetext{
${ }^{44}$ Sadjijono, Op.Cit, hlm. 56.
}

Indonesia Tahun 2002 Nomor 2, pengertian Anggota Kepolisian adalah pegawai negeri pada Kepolisian Negara Republik Indonesia. Anggota kepolisian merupakan pejabat kepolisian yang berdasarkan Undang-undang memiliki tugas dan kewewenang dalam menjalankan fungsi dari lembaga kepolisian.

$$
\text { Fungsi kepolisian di }
$$
Indonesia meliputi tugas dan kewenangan Kepolisian secara umum, artinya segala kegiatan pekerjaan yang dilaksanakan oleh polisi yang meliputi kegiatan pencegahan (preventif) dan penegakan hukum atau represif. ${ }^{45}$

Fungsi kepolisian menurut pasal 2 Undang-undang Nomor 2 tahun 2002 tentang Kepolisian Negara Republik Indonesia Lembaran Negara Republik Indonesia Tahun 2002 Nomor 2 adalah salah satu fungsi pemerintahan negara di bidang pemeliharaan keamanan dan ketertiban masyarakat, penegakan hukum, perlindungan, pengayoman, dan pelayanan kepada masyarakat. Hal tersebut dipertegaskan dalam Pasal 14 ayat 1 huruf g Undang-undang Nomor 2 tahun 2002 tentang Kepolisian Negara Republik Indonesia dinyatakan bahwa:

$\begin{array}{lr}\text { "Polisi } & \begin{array}{l}\text { berwenang } \\ \text { melakukan } \\ \text { terhadap semyidikan }\end{array} \\ \text { o, Fungsi Kepolisian Dalam } & \text { tindak } \\ \text { Good Governance, Laksbang, } \\ 005, \text { hlm. 158. }\end{array}$




$$
\begin{aligned}
& \text { pidana sesuai dengan } \\
& \text { hukum acara pidana dan } \\
& \text { peraturan perundang- } \\
& \text { undangan lainnya." }
\end{aligned}
$$

Hal tersebut merupakan fungsi polisi sebagai aparat penegak hukum. Dalam menjalankan fungsi sebagai aparat penegak hukum polisi wajib memahami asas-asas hukum yang digunakan sebagai bahan pertimbangan dalam pelaksanaan tugas, yaitu : ${ }^{46}$

a. Asas legalitas, dalam melaksanakan tugasnya sebagai penegak hukum wajib tunduk pada hukum.

b. Asas kewajiban, merupakan

kewajiban polisi dalam menangani permasalahan dalam masyarakat yang bersifat diskresi, karena belum diatur dalam hukum.

c. Asas partisipasi, dalam rangka mengamankan lingkungan masyarakat polisi mengkoordinasikan pengamanan

Swakarsa untuk mewujudkan ketaatan hukum di kalangan masyarakat.

d. Asas preventif, selalu mengkedepankan tindakan

46 Bisri Ilham, Sistem Hukum Indonesia, Grafindo Persada, Jakarta, 2004, hlm. 32. pencegahan dari pada penindakan (represif) kepada masyarakat.

e. Asas subsidaritas, melakukan tugas instansi lain agar tidak menimbulkan permasalahan yang lebih besar sebelum ditangani oleh instansi yang membidangi.

Untuk mewujudkan fungsi kepolisian sebagaimana yang telah diatur dalam Undang-undang Nomor 2 tahun 2002 tentang Kepolisian Negara Republik Indonesia Lembaran Negara Republik Indonesia Tahun 2002 Nomor 2 tersebut, kepolisian memiliki tugas dan wewenang. Tugas pokok kepolisian menurut Pasal 13 Undang-undang Nomor 2 tahun 2002 tentang Kepolisian Negara Republik Indonesia Lembaran Negara Republik Indonesia Tahun 2002 Nomor 2 tersebut, yaitu :

a. Memelihara keamanan dan ketertiban masyarakat;

b. Menegakkan hukum; dan

c. Memberikan perlindungan, pengayoman, dan pelayanan kepada masyarakat.

Rincian dari tugas-tugas pokok tersebut sebagaimana yang telah diatur dalam Pasal 14 Undang-undang Nomor 2 tahun 2002 tentang Kepolisian Negara Republik Indonesia Lembaran Negara Republik Indonesia Tahun 2002 Nomor 2, yaitu : 
a. Melaksanakan pengaturan, penjagaan, pengawalan, dan patroli terhadap kegiatan masyarakat dan pemerintah sesuai kebutuhan;

b. Menyelenggarakan segala kegiatan dalam menjamin keamanan, ketertiban, dan kelancaran lalu lintas di jalan;

c. Membina masyarakat untuk meningkatkan partisipasi masyarakat, kesadaran masyarakat, kesadaran hukum masyarakat serta ketaatan warga masyarakat terhadap hukum dan peraturan perundangundangan;

d. Turut serta dalam pembinaan hukum nasional;

e. Memelihara ketertiban dan menjamin keamanan umum;

f. Melakukan

koordinasi, pengawasan, dan pembinaan teknis terhadap kepolisian khusus, penyidik pegawai negeri sipil, dan bentukbentuk pengamanan swakarsa;

g. Melakukan penyelidikan dan penyidikan terhadap semua tindak pidana sesuai dengan

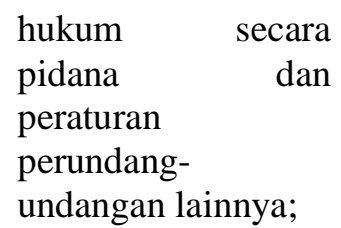

hukum secara pidana dan peraturan perundangundangan lainnya;

h. Menyelenggarakan identifikasi kepolisian, kedokteran kepolisian, laboratorium forensik dan psikologi kepolisian untuk kepentingan tugas kepolisian;

i. Melindungi keselamatan jiwa raga, harta benda, masyarakat, dan lingkungan hidup dari gangguan ketertiban dan/atau bencana termasuk memberikan bantuan dan pertolongan dengan menjunjung tinggi hak asasi manusia;

j. Melayani kepentingan warga masyarakat untuk sementara sebelum ditangani oleh instansi dan/atau pihak yang berwenang;

k. Memberikan pelayanan kepada masyarakat sesuai dengan kepentingannya dalam lingkup tugas kepolisian; serta melaksanakan tugas lain sesuai dengan peraturan perundangundangan.

Dalam rangka menyelenggarakan tugasnya tersebut, maka kepolisian secara umum memiliki kewenangan, 
sebagaimana yang telah diatur dalam Pasal 15 Undang-undang Nomor 2 tahun 2002 tentang Kepolisian Negara Republik Indonesia Lembaran Negara Republik Indonesia Tahun 2002 Nomor 2, yaitu:

a. Menerima laporan dan/atau pengaduan;

b. Membantu menyelesaikan perselisihan warga masyarakat yang dapat mengganggu ketertiban umum;

c. Mencegah dan menanggulangi tumbuhnya penyakit masyarakat;

d. Mengawasi aliran yang dapat menimbulkan perpecahan atau mengancam persatuan dan kesatuan bangsa;

e. Mengeluarkan peraturan kepolisian dalam lingkup kewenangan administratif kepolisian;

f. Melaksanakan pemeriksaan khusus sebagai bagian dari tindakan kepolisian dalam rangka pencegahan;

g. Melakukan tindakan pertama di tempat kejadian;

h. Mengambil sidik jari dan identitas lainnya serta memotret seseorang;

i. Mencari keterangan dan barang bukti; j. Menyelenggarakan Pusat Informasi Kriminal Nasional;

k. Mengeluarkan surat izin dan/atau surat keterangan yang diperlukan dalam rangka pelayanan masyarakat;

1. Memberikan bantuan pengamanan dalam sidang dan pelaksanaan putusan pengadilan, kegiatan instansi lain, serta kegiatan masyarakat;

m. Menerima dan menyimpan barang temuan untuk sementara waktu.

Untuk melaksanaan fungsi, tugas, dan kewenangan kepolisian agar sesuai dengan norma-norma yang berlaku, dan untuk membina persatuan dan kesatuan serta meningkatkan semangat kerja dan moril, diperlukan adanya peraturan disiplin anggota kepolisian yang diatur dalam Peraturan Pemerintah Nomor 2 Tahun 2003 tentang Peraturan Disiplin Anggota Kepolisian Negara Republik Indonesia Lembaran Negara Republik Indonesia Tahun 2003 Nomor 2. Peraturan disiplin anggota kepolisian tersebut berisi tentang kewajiban, larangan, sanksi dan penyelesaian pelanggaran disiplin yang dilakukan oleh anggota kepolisian.

\section{Pengertian Senjata Api}

Penggunaan senjata api pada awalnya diperuntukkan bagi TNI dan Polri. Penggunaan senjata 
api oleh Polisi merupakan bagian dari tugas perlindungan warga negara dari segi pendekatan hukum. Senjata digunakan dalam keadaan terpaksa yang mengancam keselamatan orang lain. Senjata api bersifat melumpuhkan bukan membunuh oleh karenanya senjata api Polisi bersifat tembak target dalam arti hanya diarahkan pada orang tertentu sebagai subjek hukum.

Penggunaan senjata api yang ada pada TNI diarahkan kepada musuh-musuh yang datang dari negara lain, yang esensinya adalah sebagai perimbangan kekuatan untuk pertahanan. Sedangkan senjata api yang ada pada Polri diarahkan kedalam wilayah negara dimana sasarannya adalah warga negara sebagai subjek hukum, atau orang-orang lain yang bukan warga negara Indonesia, tetapi berada di wilayah Indonesia secara sah dan karenanya wajib dilindungi oleh hukum Indonesia. Senjata yang diperuntukkan bagi Polri ini yang sejak semula dipersiapkan untuk penegakan hukum digunakan untuk keamanan, tetapi senjata api hanya digunakan untuk menghentikan perbuatan kekerasan yang mengancam jiwa warga negara, dan merupakan jalan terakhir, karena cara-cara polisi yang lebih lunak tidak membawa hasil. ${ }^{47}$

47 James Daniel Sitorus, Makalah: Teknologi Yang Dibutuhkan Dan Dikuasai Dalam Angka Pengembangan Wawasan Hankamneg Penegakan Hukum Dan Kinerja
Senjata adalah suatu alat yang digunakan untuk melukai, membunuh, atau menghancurkan suatu benda. Senjata dapat digunakan untuk menyerang maupun untuk mempertahankan diri, dan juga untuk mengancam dan melindungi. Apapun yang dapat digunakan untuk merusak (bahkan psikologi dan tubuh manusia) dapat dikatakan senjata. Senjata bisa sederhana seperti pentungan atau kompleks seperti peluru kendali balistik. $^{48}$

Senjata api adalah senjata yang melepaskan satu atau lebih proyektil yang didorong dengan kecepatan tinggi oleh gas yang dihasilkan oleh pembakaran suatu propelan, (Wikipedia Bahasa Indonesia, Ensiklopedia Bebas). ${ }^{49}$ Menurut Kamus Besar Bahasa Indonesia pengertian senjata api adalah senjata yang menggunakan bubuk mesiu.

Sedangkan menurut Undang-undang Darurat Nomor 12 Tahun 1951 tentang Senjata Api Lembaran Negara Tahun 1951 Nomor 78, Tambahan Lembaran Negara Nomor 169, pengertian Senjata api dan munisi termasuk juga segala barang sebagaimana diterangkan dalam pasal 1 ayat (1) dari Peraturan Senjata Api (vuurwaapenregeling: in, uit, door,

TNI-Polri Dalam Membina Persatuan Dan Kesatuan, Jakarta, 2000.

48 http://id.wikipedia.org/wiki/, Senjata, 15 November 2008.

49 Ibid, Senjata Api, tanggal 15 November 2008 
voer en lossing) 1936 (Stbl. 1937 No.170), yang telah diubah dengan Ordonnantie tanggal 30 Mei 1939 (Stbl. No.278), tetapi tidak termasuk dalam pengertian itu senjata-senjata yang nyata-nyata mempunyai tujuan sebagai barang kuno atau barang yang ajaib (merkwaardigheid), dan bukan pula sesuatu senjata yang tetap tidak dapat terpakai atau dibikin sedemikian rupa sehingga tidak dapat dipergunakan.

\section{Jenis Senjata Api Untuk Ijin Pinjam Pakai}

Senjata dapat dikategorikan dalam tiga jenis utama, yaitu : ${ }^{50}$

1) Siapa pemakainya, merujuk pada apa yang menggunakannya :

1. Senjata pribadi (atau senjata ringan): dibuat untuk digunakan satu orang.

2. Senjata kru: lebih besar dari senjata pribadi, membutuhkan lebih dari satu orang.

3. Senjata kendaraan: dibuat untuk dipasang dan ditembakkan dari kendaraan.

4. Senjata udara: dibuat untuk dibawa dan dipakai kendaraan udara seperti pesawat dan helikopter.

5. Senjata laut: dibuat untuk ditembakkan dari kapal atau kapal selam.

6. Senjata antariksa: dibuat untuk ditembakkan dari luar angkasa.

2) Cara pemakaian, merujuk pada cara pengoperasian senjata :

a) Artileri adalah senjata yang menembakan proyektil

${ }^{50}$ Ibid, Senjata, 15 November 2008.

berhulu ledak ke jarak yang sangat jauh.

b) Panahan adalah senjata yang memakai energi yang dihasilkan seutas tali untuk melemparkan proyektil.

c) Roket menggunakan bahan kimia untuk meluncurkan proyektil berhulu ledak.

d) Misil atau peluru kendali adalah roket yang bisa dikendalikan setelah diluncurkan.

e) Senjata api menggunakan ledakan mesiu untuk menembakkan proyektil.

f) Senjata biologi menggunakan agen biologi seperti bakteri untuk menyerang manusia atau hewan.

g) Senjata kimia menggunakan bahan-bahan kimia untuk menyerang dan meracuni manusia.

h) Senjata energi menggunakan konsentrasi energi seperti laser, listrik, suhu, atau suara.

i) Senjata peledak menggunakan ledakan untuk menghancurkan target.

j) Senjata pembakar menggunakan bahan yang bisa menghasilkan kerusakan dengan pembakaran.

k) Senjata tajam adalah alat yang ditajamkan untuk digunakan langsung untuk melukai tubuh lawan.

1) Senjata nuklir menggunakan bahan radioaktif untuk menghasilkan fusi nuklir atau fisi nuklir yang menghasilkan ledakan dasyat.

m) Senjata bunuh diri biasanya adalah bahan peledak yang diledakan oleh operator, 
dan operatornya tidak akan selamat dari ledakan itu.

3) Apa targetnya, merujuk senjata yang dirancang untuk menghancurkan benda tertentu :
a) Senjata anti-udara adalah senjata yang dirancang untuk menghancurkan
pesawat, helikopter, peluru kendali, dan benda terbang lainnya.
b) Senjata anti-personel dirancang untuk menyerang manusia (infanteri).
c) Senjata anti-kapal menargetkan kapal dan kendaraan air lainnya.
d) Senjata anti-kapal selam dibuat untuk menghancurkan kapal selam.
e) Senjata anti-tank dibuat untuk menghancurkan kendaraan lapis baja.
f) Senjata berburu adalah senjata yang dibuat untuk dipakai untuk berburu binatang.
g)

\section{Bentuk Penyalahgunaan Senjata Api yang Dilakukan Oleh Anggota Kepolisian}

Anggota kepolisian dalam menggunakan senjata api dinas tidak terlepas dari tindakan melawan hukum. Tindakan melawan hukum tersebut dapat digolongkan berupa tindak pidana dan pelanggaran disiplin. Tindak pidana yang dilakukan anggota kepolisian yang berkaitan dengan Senjata api dapat berupa penembakan terhadap sesama teman sejawat, penembakan terhadap warga sipil. Tindak pidana yang dilakukan oleh anggota kepolisian tersebut proses peradilannya dilakukan di peradilan umum menurut hukum acara pidana yang berlaku. Dalam rangka pemeriksaan terhadap anggota kepolisian guna penyidikan dilakukan oleh aparat kepolisian dengan memperhatikan kepangkatan sebagaimana telah diatur dalam Pasal 5 Peraturan Pemerintah Nomor 3 Tahun 2003 tentang Pelaksanaan Teknis Institusional Peradilan Umum Bagi Anggota Kepolisian Lembaran Negara Tahun 2003 Nomor 3, yaitu :

a) Tamtama diperiksa oleh anggota kepolisian berpangkat serendah-rendahnya Bintara;

b) Bintara diperiksa oleh anggota kepolisian berpangkat serendahrendahnya Bintara;

c) Perwira Pertama diperiksa oleh anggota kepolisian berpangkat serendah-rendahnya Bintara;

d) Perwira Menengah diperiksa oleh anggota kepolisian berpangkat serendah-rendahnya Perwira Pertama;

e) Perwira Tinggi diperiksa oleh anggota kepolisian berpangkat serendah-rendahnya Perwira Menengah.

Penyidikan tersebut dilakukan oleh satuan fungsi 
Reserse untuk menyidik tindak pidana umum. Sedangkan penuntutan terhadap terdakwa anggota kepolisian di lingkungan peradilan umum dilakukan oleh Jaksa Penuntut Umum sesuai dengan peraturan perundangundangan yang berlaku. ${ }^{51}$

Dalam Pasal 12 Peraturan Pemerintah Nomor 3 Tahun 2003 tentang Pelaksanaan Teknis Institusional Peradilan Umum Bagi Anggota Kepolisian, Lembaran Negara Tahun 2003 Nomor 3 :

"Pemeriksaan di muka sidang pengadilan dilakukan oleh Hakim Peradilan Umum sesuai dengan hukum acara dan peraturan perundang-undangan yang berlaku"

Sedangkan pelanggaran disiplin yang dilakukan anggota kepolisian yang berkaitan dengan senjata api berupa kelalaian anggota kepolisian yang menyebabkan salah tembak, kelalaian anggota yang menyebabkan senjata api dan/atau peluru hilang, meminjamkan senjata api beserta peluru kepada orang lain. Pelanggaran disiplin yang dilakukan oleh anggota kepolisian tersebut proses

51 Pasal 11 Peraturan Pemerintah Nomor 3 Tahun 2003 tentang Pelaksanaan Teknis Institusional Peradilan Umum Bagi Anggota Kepolisian Lembaran Negara Tahun 2003 Nomor 3. penyelesaiannya dilakukan dalam sidang disiplin anggota kepolisian yang diselenggarakan atas perintah dari Ankum. Penyidikan dan pemeriksaan terhadap kasus pelanggaran disiplin anggota kepolisian tersebut dilakukan oleh satuan fungsi Provos. Menurut Pasal 16 ayat 1 Peraturan Pemerintah Nomor 2 Tahun 2003 tentang Peraturan Disiplin Anggota Kepolisian, Pejabat yang berwenang menjatuhkan hukuman disiplin adalah Ankum, dan/atau Atasan Ankum. Sedangkan dalam Pasal 16 ayat 2 Peraturan Pemerintah Nomor 2 Tahun 2003 yaitu :

"Atasan Ankum
sebagaimana dimaksud
dalam ayat (1) huruf b,
berwenang memeriksa
dah memutus atas
keberatan yang diajukan
oleh terhukum"

\section{Metode Penelitian}

\section{Type Penelitian}

Tipe penelitian hukum yang dipergunakan adalah yuridis normatif (hukum normatif). Metode penelitian hukum normatif adalah suatu prosedur penelitian ilmiah untuk menemukan kebenaran berdasarkan logika keilmuan hukum dari sisi normatifnya ${ }^{52}$. Oleh karena itu penelitian hukum ini difokuskan untuk

52 Johnny Ibrahim, Teori Metode

Penelitian Normatif, Banyu Media

Publishing, Malang 2005. Hal 47 
mengkaji penelitian hukum tentang kaidah-kaidah atau norma-norma dalam hukum positif yang terkait dengan prosedur Penanganan Dan Sanksi Disiplin Terhadap Penyalahgunaan Senjata Api Dinas.

\section{Pendekatan Masalah}

Oleh karena type penelitian yang digunakan adalah type penelitian yuridis normatif, maka pendekatan masalah yang digunakan adalah pendekatan perundangundangan (Statute Approach). Pendekatan tersebut melakukan pengkajian pengaturan perundang-undangan yang berhubungan dengan pokok permasalahan. Selain itu juga digunakan pendekatan kansep (Conseptual Approach), pendekatan ini maksudnya melihat konsep prosedur Penanganan Dan Sanksi Disiplin Terhadap Penyalahgunaan Senjata Api Dinas..

\section{Bahan Hukum}

a. Bahan Hukum Primer

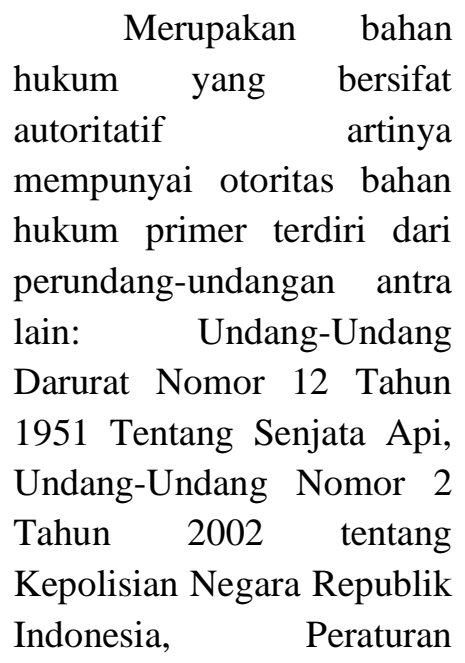

Pemerintah No. 2 Tahun 2003 Tentang Peraturan Disiplin Anggota Kepolisian Negara Republik Indonesia.

b. Bahan sekunder

Berupa semua
publikasi tentang hukum
yang bukan merupakan
dokumen-dokumen resmi,
yaitu berupa buku teks,
kamus-kamus hukum,
jurnal-jurnal hukum dasar,
komentar-komentar atas $^{\text {putusan pengadilan. }}{ }^{53}$

\section{Prosedur Pengumpulan} Bahan-bahan

Baik bahan primer maupun bahan sekunder dikumpulkan berdasar-kan topik permasalahan yang telah dirumuskan dan diklasifikasi menurut sumber dan hirarkinya untuk dikaji secara komprehensif.

\section{Pengolahan dan Analisis} Bahan Hukum

Adapun bahan yang diperoleh dalam penelitian studi kepustakaan, aturan perundang-undangan, yang penulis uraikan dan dihubungkan sedemikian rupa, sehingga disajikan dalam penulisan yang lebih sistematis guna menjawab perumusan masalah yang dirumuskan. Cara pengolahan data dilakukan secara deduktif

${ }^{53}$ Peter Mahmud Marzuki. Penelitian Hukum. Universitas Air Langga. Surabaya. 2005. h 
yakni menarik kesimpulan dari suatu permasalahan yang bersifat umum terhadap permasalahan kongkrit yang dihadapi.

D. Hasil Penelitan dan Pembahasan

1. Tugas dan Kewenangan Provos dalam Kepolisian

Pasal 1 Nomor 15

Peraturan Pemerintah Nomor 2

Tahun 2003 tentang Peraturan

Disiplin Anggota Kepolisian

Negara Republik Indonesia

Lembaran Negara Republik Indonesia Tahun 2003 Nomor 2, pengertian Provos adalah satuan fungsi pada Kepolisian Negara Republik Indonesia yang bertugas membantu pimpinan untuk membina dan menegakkan disiplin serta memelihara tata tertib kehidupan anggota Kepolisian Negara Republik Indonesia.

Di salah satu bagian dari struktur organisasi Polri, provos merupakan bagian dari Propam (Profesi dan Pengamanan). Secara umum Provos memiliki kewenangan yang diatur dalam Pasal 22 Peraturan Pemerintah Nomor 2 Tahun 2003 tentang Peraturan Disiplin Anggota Kepolisian Negara Republik Indonesia Lembaran Negara Republik Indonesia Tahun 2003 Nomor 2, yaitu :
a. Melakukan pemanggilan dan pemeriksaan;
b. Membantu pimpinan menyelenggarakan

pembinaan dan penegakan disiplin, serta memelihara tata tertib kehidupan anggota Kepolisian Negara Republik Indonesia;

c. Menyelenggarakan sidang disiplin atas perintah Ankum;

d. Melaksanakan putusan Ankum.

Struktur Organisasi Divisi Profesi dan Pengamanan Polri adalah sebagai berikut :

Tugas pokok Subbid Provos, yaitu :

a. Subbid Provos adalah unsur pelaksana pada bidang Propam (Profesi dan Pengamanan) yang berada di bawah Kabid Propam.

b. Subbid Provos bertugas menyelenggarakan dan membina fungsi Provos yang meliputi pembinaan disiplin, penegakan hukum dan penyelesaian perkara pelanggaran disiplin.

c. Subbid Provos dipimpin oleh Kepala Subbid Provos yang bertanggungjawab kepada Kabid Propam.

d. Subbid Provos dalam melaksanakan tugas kewajibannya dibantu oleh :

a) Kepala Urusan Pembinaan Disiplin yang 
disingkat Kaur Binplin,

b) Kepala Urusan Penegakan Hukum yang disingkat Kaur Gakkum.

e. Subbid Provos terdiri dari sejumlah unit yang masingmasing dipimpin oleh Kepala Unit yang disingkat Kanit.

Tugas pokok Kaur Binplin, yaitu :
a. Membantu
Kasubbid Provos dalam
penyelenggaraan
dan penegakan
disiplin bagi
anggota POLRI/
PNS POLRI.
b. Membantu
pimpinan dalam
melakukan
penyidikan terhadap
anggota POLRI/
PNS POLRI yang
melakukan
pelanggaran disiplin
sesuai yang diatur
dalam PP No.2
Tahun 2003.
c. Melakukan
pemeriksaan
terhadap identitas
diri maupun surat-
surat lain kepada
anggota POLRI/
PNS POLRI.
d. Melaksanakan
putusan sidang
disiplin yang
diputuskan Ankum
yang berupa
penempatan dalam
tahanan.
e. Dalam
melaksanakan tugas

sehari-hari Kaur Binplin dibantu 2 Kanit Hartib A, B.

f. Ur Binplin dipimpin oleh Kuala Ur Binplin yang bertanggungjawab kepada Kasubbid Provos.

Tugas pokok Kaur Gakkum, yaitu :

a. Membantu

Kasubbid Provos dalam

penyelenggaraan

dan penekakan

disiplin bagi

anggota POLRI/

PNS POLRI.

b. Membantu

pimpinan dalam

melakukan

penyidikan terhadap anggota POLRI/

PNS POLRI yang melakukan

pelanggaran disiplin sesuai yang diatur dalam PP No. 2

Tahun 2003.

c. Melakukan pemeriksaan

terhadap identitas diri maupun suratsurat lain kepada anggota POLRI/ PNS POLRI.

d. Melaksanakan

putusan sidang disiplin yang diputuskan Ankum yang berupa penempatan dalam tempat khusus.

e. Dalam melaksanakan tugas sehari-hari Kaur Gakkum dibantu 1 Kanit Idik.

f. Ur Gakkum dipimpin oleh 
Kepala Ur Gakkum yang

bertanggungjawab

kepada Kasubbid

Provos.

Tugas Pokok Paminal

antara lain:

a. Mengawasi

peminjaman/pemeg

angan senjata api dinas.

b. Member

rekomendasi

berdasarkan

penelitian terhadap personil yang akan meminjam/memakai senjata api dinas.

Dilihat dari tugas dan kewenangan provos dapat disimpulkan peran provos dalam kepolisian yaitu membantu pimpinan untuk membina, menegakkan disiplin, dan memelihara tata tertib anggota dalam kepolisian.

\section{B. Prosedur Penanganan dan Sanksi Disiplin Terhadap Penyalaggunaan Senjata Api Dinas}

a. Prosedur penanganan Penyalahgunaan Senjata Api Dinas

Penyalahgunaan senjata api dinas yang dilakukan karena kelalaian dari anggota kepolisian merupakan pelanggaran disiplin. Menurut Pasal 25 Peraturan Pemerintah Nomor 2 Tahun 2003 tentang Peraturan Disiplin Anggota Kepolisian Negara Republik Indonesia Lembaran Negara Republik Indonesia Tahun 2003 Nomor 2, penyelesaian perkara pelangaran disiplin dilaksanakan melalui tahapan, yaitu :

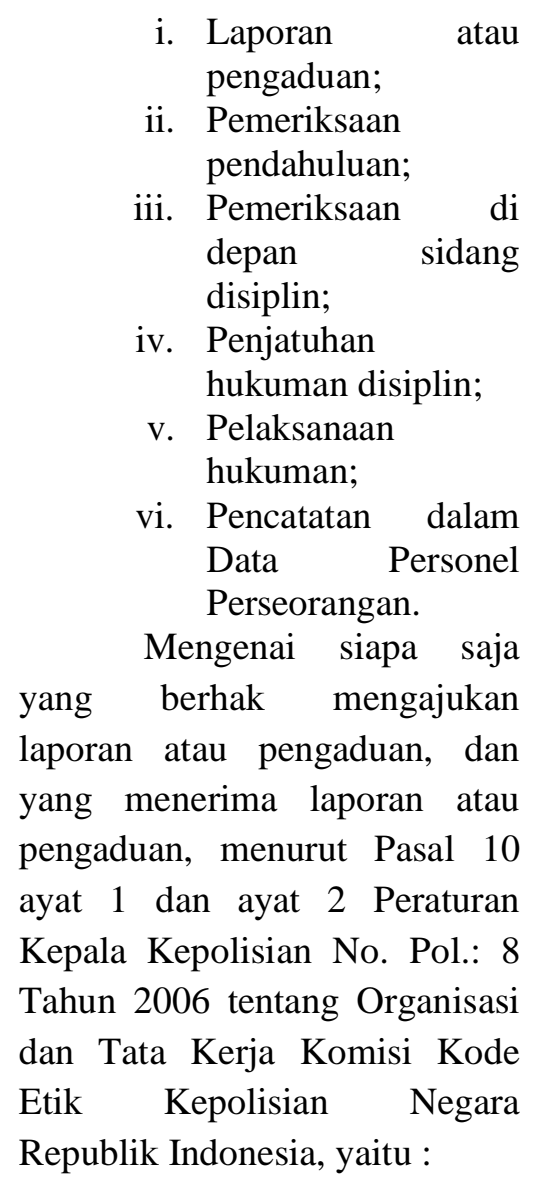

1. Menurut ayat 1 yang berhak mengajukan laporan atau pengaduan, yaitu :
a. Masyarakat;
b. Anggota Polri;
c. Sumber lain yang dapat dipertanggungjawabkan.

2. Menurut ayat 2 penerima laporan atau pengaduan dilaksanakan oleh pengemban fungsi Propam (Profesi dan Pengamanan) di setiap jenjang organisasi Polri, yang selanjutnya melakukan pemeriksaan pendahuluan atas laporan atau pengaduan dimaksud.

Menurut Pasal 14 ayat 3

Peraturan Pemerintah Nomor 2

Tahun 2003 tentang Peraturan Disiplin Anggota Kepolisian, 
mengenai penyelesaian

pelanggaran disiplin, yaitu :

"Penentuan

penyelesaian

pelanggaran Peraturan

Disiplin melalui sidang

disiplin merupakan

kewenangan Ankum.”

Pada Pasal 16 ayat 1 Peraturan Pemerintah Nomor 2

Tahun 2003 tentang Peraturan Disiplin Anggota Kepolisian, pejabat yang berwenang menjatuhkan tindakan disiplin adalah Ankum dan/atau Atasan Ankum. Pengertian Atasan yang berhak menghukum (Ankum) menutut Pasal 1 nomor 13 Peraturan Pemerintah Nomor 2 Tahun 2003 tentang Peraturan Disiplin Anggota Kepolisian, adalah atasan yang karena jabatannya diberi wewenang menjatuhkan hukuman disiplin kepada bawahan yang dipimpinnya.

Ankum secara berjenjang digolongkan menjadi :
a. Ankum berwenang penuh.
b. Ankum berwenang terbatas.
c. Ankum berwenang sangat terbatas.
Ankum dilingkungan

Polri terdiri dari :

a. Ankum tingkat pusat, yaitu :

1. Ankum berwenang penuh, yaitu :
- KAPOLRI;

- WAKAPO

LRI;

- IRWASUM ;

- PARA

KABA;

- Kepala BNN;

- PARA DEPUTI;

- KALEMDI KLAT, KASESPIM , Gubernur;

- AKPOL/PT IK;KOORS AHLI/SAH LI KAPOLRI;

- PARA KADIV;

- KAKORBR IMOB;

- PARA KARO;

- PARA ITWIL;

- PARA DIREKTU $\mathrm{R}$;

- PARA KAPUSKA SECAPA, KA SELAPA, KARUMKI $\mathrm{T}$;

- SES NCB INTERPOL Indonesia;

- KADENM $\mathrm{A}$;

- KASETUM ;

- PARA KAPUSDI $\mathrm{K}$;

- KETUA INKOPPOL 
(diluar

struktur);

- KOORSPRI PIM.

2. Ankum berwenang terbatas, yaitu :

- IRBIT;

- SES DAN WADIR;

- KABAG;

- KABID;

- KADEN pada DIVPROP

AM dan

BAINTEL

KAM

POLRI;

- KASAT pada KORBRIM $\mathrm{OB}$, PUSDOKK ES dan PUSKU POLRI;

- KANIT pada BARESKRI M POLRI;

- PARA KADEP.

3. Ankum berwenang sangat terbatas, yaitu :

- KASUBBA G;

- KASUBBI D;

- KANIT pada BAINTEL KAM dan DIVPROP

AM

POLRI;
- $\mathrm{KASI} / \mathrm{KAD}$ EN pada KORBRIM OB POLRI;

- PARA PASDEP.

b. Ankum tingkat kewilayahan :

1. Tingkat Polda :

a) Ankum berwenang penuh, yaitu

- KAPO LDA;

- WAKA POLD A;

- IRWAS DA;

- PARA KARO;

- PARA DIREK TUR;

- KASA D BRIMO BDA;

- PARA KABID ;

- KA SPN;

- KASET UM;

- KADE NMA;

- KAPA

LA BND;

- KETU

A PUSKO PPOL (diluar struktur ).

b) Ankum berwenang 
terbatas,

yaitu :

- IRBID;

- KABA $\mathrm{G}$;

- KASU BDIT;

- KASU BBID;

- KADE $\mathrm{N}$;

- KASA $\mathrm{T}$.

c) Ankum berwenang sangat terbatas, yaitu :

- KASU BBAG;

- KASU BBID;

- KANIT ;

- KASI;

- DANKI ;

- KAUR.

2. Tingkat

Poltabes,

Polwil/Tabes :

a) Ankum berwenang penuh, yaitu

- Kapolw il/Kapol wiltabe s/Kapol tabes;

- Wakap olwil/W akapol wiltabe s/Waka poltabe $\mathrm{s}$.

b) Ankum yang berwenang terbatas,

yaitu :

- PARA

KABA

$\mathrm{G}$;

- KASA

$\mathrm{T}$;

- DANKI BRIMO

B.

c) Ankum yang berwenang sangat terbatas, yaitu :

- PARA

KASU

BBAG;

- PARA

KANIT

;

- PARA

DANT

ON

BRIMO

B.

3. Tingkat

Polres/Tro/Ta :

a) Ankum berwenang penuh, yaitu

- Kapolre s/TRO/ TA;

- Wakap olres/T RO/TA;

b) Ankum berwenang terbatas, yaitu :

- PARA KABA $\mathrm{G}$;

- KASA $\mathrm{T}$;

- KAPO LSEK.

c) Ankum berwenang 54 | P a g e 
sangat

terbatas,

yaitu :

- PARA

KASU

BBAG;

- PARA

KANIT

POLRE

$\mathrm{S}$.

Dalam melakukan

pemeriksaan yang dilakukan

oleh provos, mengenal jenjang kepangkatan, yaitu :

1. Terperiksa berpangkat

Tamtama

(TA)/

Bintara (BA)/

Perwira Pertama

(PAMA) serendahrendahnya diperiksa oleh pejabat yang berpangkat Bintara (BA).

2. Terperiksa

berpangkat Perwira

Menengah

(PAMEN)

serendahrendahnya

diperiksa oleh

pejabat yang

berpangkat Perwira

Pertama (PAMA).

3. Terperiksa

berpangkat Perwira

Tinggi (PATI)

serendah-rendahnya

diperiksa oleh

pejabat yang

berpangkat Perwira

Menengah

(PAMEN).

Pemeriksaan perkara

pelanggaran disiplin yang

dilakukan oleh anggota polisi

khususnya provos didasarkan pada :

1. Laporan;

2. Tertangkap tangan;
3. Temuan petugas.

Mekanisme

penyelesaian perkara

pelanggaran disiplin yang

dilakukan anggota kepolisian

adalah sebagai berikut:

Pelanggaran disiplin seperti penyalahgunaan senjata api dapat dilaporkan kepada provos atau kepada pimpinan, Pamapta, Yanduan, Yanmas. Jika dilaporkan atau diadukan kepada pimpinan ataupun kepada Pamapta, Yanduan, maupun Yanmas maka akan diteruskan atau diserahkan kepada provos. Hasil dari laporan atau pengaduan tersebut akan diperiksa oleh provos. Provos mempunyai kewenangan untuk melakukan pemanggilan dan pemeriksaan. Setelah selesai melakukan pemeriksaan maka hasil pemeriksaan disusun dalam satu berkas perkara pelanggaran disiplin. Jika berkas tersebut sudah lengkap maka dilimpahkan kepada Ankum. Ankum dapat meminta pendapat dan saran hukum dari satuan fungsi pembinaan hukum kepolisian guna menentukan perlu atau tidaknya dilakukan sidang disiplin.

\begin{tabular}{lrr}
\multicolumn{2}{c}{ Apabila } & pelanggaran \\
disiplin & tersebut & merupakan \\
pelanggaran & disiplin & maka \\
dilakukan & sidang & disiplin. \\
Putusan dari & sidang & disiplin \\
ditetapkan & dengan & Surat \\
Keputusan & Hukuman & Disiplin \\
(SKHD) dan disampaikan & dan dera \\
kepada terhukum. & Apabila \\
pelanggaran & disiplin & tersebut
\end{tabular}


merupakan pelanggaran Kode Etik Profesi Polri maka dilakukan Sidang Komisi Kode Etik. Putusan dari sidang Komisi Kode Etik tersebut berupa pemberian sanksi administrasi yang berupa rekomendasi untuk dapat atau tidaknya Diberhentikan Tidak Dengan Hormat (PTDH) atau Dengan Hormat dari dinas Polri (PDH) dan putusan tersebut besifat final.

Hasil putusan dari kedua persidangan diserahkan kepada provos untuk dilaksanakan. Untuk perkara pelanggaran disiplin, jika hukuman tersebut sudah dilaksanakan maka anggota yang telah menjalani hukuman tersebut harus dikembalikan pada keadaan semula selambatlambatnya 30 hari setelah berakhirnya masa hukuman disiplin tersebut. Anggota kepolisian yang sudah selesai menjalani hukuman tersebut akan diawasi selama 6 bulan. Pengawasan tersebut bekaitan dengan kelakukan anggota tersebut. Kelakuan anggota tersebut akan dinilai oleh provos. Hasil penilaian tersebut berbentuk Surat Rekomendasi Penilaian. Rekomendasi Penilaian tersebut bertujuan untuk pembinaan karier anggota yang telah selesai menjalani hukuman disiplin.

\section{E. Penutup}

\section{Kesimpulan}

Setelah dilakukan analisis terhadap data yang diperoleh penulis dalam penelitian dengan menggunakan teori maupun bahan kepustakaan yang ada tentang permasalahan dalam penulisan ini dapat disimpulkan bahwa:

a. Kewenangan provos dalam menghadapi penyalahgunaan senjata api oleh anggota kepolisian yang merupakan pelanggaran disiplin yang diatur dalam Pasal 22 Peraturan Pemerintah Nomor 2 Tahun 2003 adalah melakukan pemanggilan dan pemeriksaan yang berupa penyelidikan dan penyidikan, membantu pimpinan menyelenggarakan sidang disiplin, memelihara tata tertib kehidupan anggota kepolisian, serta melaksanakan putusan Ankum. Tanpa adanya perintah dari Atasan Yang Berhak Menghukum (Ankpm), provos tidak mempunyai kewenangan dalam menjatuhkan hukuman disiplin. Kewenangan untuk menjatuhkan hukuman disiplin tersebut ada pada Atasan Ankum dan/atau Ankum. Kendala yang dihadapi provos sebagai aparat penegak disiplin dalam Kepolisian dapat berupa pemeriksaan terhadap anggota kepolisian yang dapat bersifat subjektif, pemeriksaan yang dilakukan secara interen dapat mengakibatkan pemeriksaan yang tidak objektif.

b. Menurut Pasal 25 Peraturan Pemerintah Nomor 2 Tahun 2003 tentang Peraturan Disiplin Anggota Kepolisian Negara Republik Indonesia Lembaran Negara Republik Indonesia, bahwa penyelesaian perkara pelangaran disiplin dilaksanakan melalui tahapan, yaitu : 
1) Laporan atau pengaduan;

2) Pemeriksaan pendahuluan;

3) Pemeriksaan di depan sidang disiplin;

4) Penjatuhan hukuman disiplin;

5) Pelaksanaan hukuman;

6) Pencatatan dalam Data Personel Perseorangan.

Mengenai siapa saja yang berhak mengajukan laporan atau pengaduan, dan yang menerima laporan atau pengaduan, menurut Pasal 10 ayat 1 dan ayat 2 Peraturan Kepala Kepolisian No. Pol.: 8 Tahun 2006 tentang Organisasi dan Tata Kerja Komisi Kode Etik Kepolisian Negara Republik Indonesia.

\section{Saran}

Berdasarkan hasil penelitian
dan kesimpulan yang telah
diuraikan, maka penulis memberi
saran yaitu agar dalam pemberian
izin pinjam pakai senjata dinas
lebih dipeketat sehingga dapat
meminimalisir penyalahgunaan
senjata api oleh anggota polisi,
proses lebih intensif dalam
melakukan psikotes, pengawasan
dan pemeriksaan yang dilakukan
secara berkala terhadap izin pinjam
pakai senjata api beserta pelurunya,
dan juga terhadap pemakaian senjata
api beserta peluru tersebut. Ankum
diharapkan dapat memberikan
sanksi yang lebih tegas dan objektif
kepada anggota polisi yang
melakukan penyalahgunaan senjata
api sehingga dapat menjadi acuan
bagi pemegang senjata api agar
lebih berhati-hati dan bijaksana
dalam menggunakan senjata api

dalam menjalankan tugas dan tanggungjawabnya sebagai aparat yang melindungi, mengayomi dan melayani masyarakat.

\section{DAFTAR PUSTAKA}

Buku

Bisri Ilham, 2004, Sistem Hukum Indonesia, Grafindo Persada, Jakarta.

Pudi Rahardi, 2007, Hukum Kepolisian (Profesionalisme dan Reformasi Polri), Laksbang Mediatama, Surabaya.

Sadjijono, 2008, Etika Profesi Hukum: Suatu Telaah Filosofis terhadap Konsep dan Implementasi dalam Pelaksanaan Tugas Profesi Polisi, Laksbang Mediatama, Surabaya.

Sadjijono, 2005, Fungsi Kepolisian Dalam Pelaksanaan Good Governance, Laksbang, Surabaya.

\section{Makalah}

James Daniel Sitorus, 2000, Makalah: Teknologi Yang Dibutuhkan Dan Dikuasai Dalam Angka Pengembangan Wawasan Hankamneg, Penegakan Hukum Dan Kinerja TNI-Polri Dalam Membina Persatuan Dan Kesatuan, Jakarta. 


\section{Peraturan Perundang-undangan}

Undang-Undang Darurat Nomor 12

Tahun 1951 Tentang Senjata Api.

Undang-Undang Nomor 2 Tahun 2002

tentang Kepolisian Negara

Republik Indonesia.

Peraturan Pemerintah No. 2 Tahun 2003

Tentang Peraturan Disiplin

Anggota Kepolisian Negara

Republik Indonesia.

Peraturan Pemerintah Nomor 3 Tahun 2003 tentang Pelaksanaan Teknis Institusional Peradilan Umum Bagi Anggota Kepolisian.

Keputusan Kapolri Nomor 32 Tahun 2003 Tentang Kode Etik Kepolisian Negara Republik Indonesia.

Keputusan Kapolri No. Pol.: 42/IX/2004 Tentang Atasan Yang Berhak Menghukum Di Kepolisian.

Keputusan Kapolri No. Pol: 43/IX/2004

Tentang Tata Cara Penyelesaian Pelanggaran Disiplin Anggota Kepolisian.

Keputusan Kapolri No. Pol.: 44/IX/2004 Tentang Tata Cara Sidang Disiplin Anggota Kepolisian. 


\title{
PELACURAN DAN PENANGGULANGANNYA DALAM PERSPEKTIF POLITIK HUKUM PIDANA
}

\author{
Jatmiko Winarno, SH,MH
}

\begin{abstract}
Abstrak
Pelacuran sebagai sebuah nama yang diberikan untuk suatu perbuatan yang di dalamnya terlibat beberapa orang dalam suatu peristiwa. Perbuatan di mana seorang perempuan menyerahkan dirinya untuk berhubungan kelamin dengan lawan jenisnya yang mengharapkan bayaran berupa uang atau bentuk lainnya. Pelacuran merupakan masalah sosial dalam kehidupan bermasyarakat, karena merugikan keselamatan, ketentraman, kemakmuran jasmani dan rohani. Hal ini pun menjadi sesuatu yang nyata agar segera ditanggulangi bila dihubungkan dengan cara pandang agama dan adat tradisi suku bangsa di Indonesia.

Masalah pelacuran harus dilihat sebagai gejala sosial yang nampak jelas bertentangan dengan ketertiban dan kehidupan masyarakat secara umum. Akibat yang ditimbulkan akan menghambat proses perkembangan pada suatu masyarakat. Namun demikian terlihat tidak ada suatu kaidah hukum dari negara manapun yang mampu meniadakan pelacuran dalam arti menindak gejala tersebut seperti halnya kejahatan semacam pembunuhan, pencurian, penipuan dan lain sebagainya yang dapat menjatuhkan sanksi, dengan tegas baik hukuman mati, hukuman penjara, maupun hukuman denda.
\end{abstract}

\section{Kata Kunci : Pelacuran}

\section{A. Pendahuluan}

\section{Latar Belakang Masalah} Hampir semua negara di dunia ini, baik negara maju, berkembang, maupun negara miskin sekalipun menghadapi masalah tersendiri dalam menangani problem sosial, terutama berupa pelacuran. Banyak dibaca dalam surat kabar, majalah, kajian buku maupun ulasan-ulasan mengenai pelacuran dan penanggulangannya, namun ada kecenderungan masalah pelacuran ini tidak memperlihatkan tendensi menurun. Malahan penanggulangan gejala sosial tertua dan abadi ini semakin kurang menggigit.

Pelacuran sebagai sebuah nama yang diberikan untuk suatu perbuatan yang di dalamnya terlibat beberapa orang dalam suatu peristiwa. Perbuatan di mana seorang perempuan menyerahkan dirinya untuk berhubungan kelamin dengan lawan jenisnya yang mengharapkan bayaran berupa uang atau bentuk lainnya. Pelacuran merupakan masalah sosial dalam kehidupan bermasyarakat, karena merugikan keselamatan, ketentraman, kemakmuran jasmani dan rohani. Hal ini pun menjadi sesuatu yang nyata agar segera ditanggulangi bila dihubungkan dengan cara pandang agama dan adat tradisi suku bangsa di Indonesia.

Masalah pelacuran harus dilihat sebagai gejala sosial yang 